\title{
依兰陨石坑: 我国东北部一个新发现的撞击构造
}

陈鸣 ${ }^{1,2 *}$, 谢先德 ${ }^{2}$, 肖万生 ${ }^{2}$, 谭大勇 ${ }^{2}$

1. 中国科学院广州地球化学研究所, 同位素地球化学国家重点实验室, 广州 510640;

2. 中国科学院矿物学与成矿学重点实验室, 广州 510640

*联系人, E-mail: mchen@gig.ac.cn

2019-11-03 收稿, 2019-12-03 修回, 2019-12-05 接受, 2019-12-24 网络版发表

中国科学院B类战略性先导科技专项(XDB18010405)、国家自然科学基金(41672032，41921003)和中国科学院广州地球化学研究所所长基金 (2019)资助

摘要 依兰陨石坑, 一个直径 $1.85 \mathrm{~km}$ 的碗形撞击构造, 发现于我国黑龙江省中部的低山丘陵地区.该陨石坑坐落在 白严纪花岗岩基岩上, 大部分坑缘保存状态良好, 坑体南部占总长度约三分之一的坑缘缺失. 坑底堆积的花岗岩质 撞击角砾岩中石英多组面状变形页理(PDFs)的发现, 提供了确丵的冲击变质证据, 证实了该坑的星球撞击起源. 坑 区地形地貌、地质构造、撞击角砾岩和坑底湖相沉积物产状等均与一个星球撞击场所的特征相吻合. 距今大约 1 万年前, 南部坑缘在特定外动力地质作用下发生方向性的侵蚀和搬运, 造成坑缘大规模缺失.

关键词依兰陨石坑, 撞击构造, 冲击变质, 面状变形页理, 侵蚀

地球自形成以来经历了无数小行星、彗星和大流 星体的撞击. 地球上已发现的星球撞击构造(陨石坑)就 是一部分碰撞事件的记录或遗迹. 随着时间推移, 地球 上形成的大部分陨石坑在地质作用之下不断受到掩 埋、侵蚀、破坏, 直至消失. 迄今为止, 世界上共发现 了190个陨石坑, 其中仅有1个陨石坑位于中国境内 ${ }^{[1 ~ 3]}$, 即辽宁岫岩陨石坑 ${ }^{[4]}$. 作为一种广泛存在的宇宙地质构 造, 全球陨石坑分布的不均一性引起了科学界的关 注 $^{[5]}$. 中国陆地面积约占世界陆地总面积的 $1 / 15$. 基于 多样性的自然地理和地质环境, 在我国发现新陨石坑 的可能性极大.

宇宙星球之间超高速碰撞产生的强烈冲击波在靶 区岩石中传播可引起瞬间的高温高压, 导致岩石和矿 物发生一系列物理和化学的变化, 发生冲击变质 ${ }^{[6 \sim 10]}$. 除了撞击事件以外，地球上任何地质作用都不可能在 地表产生导致岩石和矿物发生冲击变质所需要的极端 高温高压条件. 历经长达数十年的探索和实践, 科学界
已经普遍认识到地表岩石和矿物在星球超高速撞击下 发生的冲击变质现象是寻找和鉴别地球陨石坑遗迹的 诊断性证据 ${ }^{[6,9,10]}$. 根据岩石和矿物的冲击变质判断标 准，近几十年来世界各地不断有陨石坑被发现和证实. 经过重点开展岩石和矿物冲击变质特征调查, 我们最 近在中国东北地区的黑龙江省发现了一个新的星球撞 击构造, 即依兰陨石坑.

\section{1 研究方法}

通过野外地质调查了解依兰陨石坑及周边地区的 地形地貌、地质构造、岩石和地层的产状和特征，采 集相关的岩石(花岗岩)、土壤和湖相沉积物样品. 采集 到的块状岩石样品磨制成抛光薄片. 细粒的岩石和矿 物碎屑样品用环氧树脂和硬化剂固结成为块状样品, 然后制成抛光薄片. 利用光学显微镜, 调查薄片中岩石 和矿物的冲击变质特征, 特别是石英面状变形页理 (PDFs)的发育特征. 此外, 在显微镜下从碎屑样品中挑 
选出部分石英颗粒进行直接的观察和分析.

利用安装在光学显微镜上的四轴弗氏旋转台, 测 定薄片上石英颗粒中PDFs的结晶学方位. 基本操作程 序为: 测量每个石英颗粒的光轴 $(C$-轴)和垂直于各组 PDFs的极点位置，将数据标绘到吴氏网上，利用吴氏 网进行极射赤平投影操作, 数据投影结果与标准的石 英PDFs极射赤平投影模板对照 ${ }^{[11]}$, 获得各组PDFs的结 晶学方位.

土壤和湖相沉积物的 ${ }^{14} \mathrm{C}$ 年代测定在同位素国家重 点实验室和有机地球化学国家重点实验室完成. 在每 个原始土壤和湖湘沉积物样品中提取 $3 \sim 5 \mathrm{~g}$ 样品. 用 $1 \mathrm{~mol} / \mathrm{L} \mathrm{HCl}$ 漂洗样品和除去碳酸盐. 处理后的样品在 烤箱中加热至 $70^{\circ} \mathrm{C}$ 干燥. 随后, 样品被放置到含有银丝 和粒状 $\mathrm{CuO}$ 的密封真空石英管中高温氧化, 温度为 $850^{\circ} \mathrm{C}$, 加热时长 $2 \mathrm{~h}$, 将样品中有机碳转变为 $\mathrm{CO}_{2}$. 采用 $\mathrm{Xu}$ 等人 ${ }^{[12]}$ 的方法, 纯化 $\mathrm{CO}_{2}$ 气体并将其转变为石墨. 利 用碳十四专用加速器质谱仪(NEC $0.5 \mathrm{MV} \quad 1.5 \mathrm{SDH}-1$ $\mathrm{AMS}$ )测定石墨靶样品的 ${ }^{14} \mathrm{C}$ 数据, 仪器分析精度为 $0.3 \%$, 采用Calib 7.0 软件IntCal13曲线计算 ${ }^{14} \mathrm{C}$ 数据.

\section{2 结果}

\section{1 地理和地质背景}

依兰陨石坑位于我国黑龙江省哈尔滨市依兰县境 内, 地理坐标为: 北纬 $46^{\circ} 23^{\prime} 03^{\prime \prime}$, 东经 $129^{\circ} 18^{\prime} 40^{\prime \prime}$. 依兰 县地处东北三江平原西部边缘, 为低山丘陵地区, 属中 温带大陆性季风气候. 陨石坑位于依兰县城驻地依兰 镇的西北方向大约 $18 \mathrm{~km}$ 处, 坐落在小兴安岭西南部的 边缘地带. 坑区大部分面积被茂密的白桦树林覆盖, 仅 局部区域被开发为大豆和玉米耕地. 巴兰河从西北往 东南方向流经陨石坑东部, 在离陨石坑东南方向大约 $19 \mathrm{~km}$ 处注人松花江.

该区域大地构造位置属于东亚造山带东部，自新 元古代晚期以来构造和岩浆活动强烈 ${ }^{[13]}$. 主要的侵人 火成岩包括二叠纪和白严纪花岗岩等. 主要的沉积岩 包括新元古代晚期、二叠纪、侏罗纪、白严纪、新生 代和第四纪等地层. 依兰陨石坑坐落在白严纪花岗岩 基岩上(图1).

\section{2 陨石坑地形地貌和地质特征}

依兰陨石坑直径为 $1.85 \mathrm{~km}$ ，坑体总体呈现为碗状 形态, 部分坑缘缺失(图2). 现存的坑缘明显高出周围

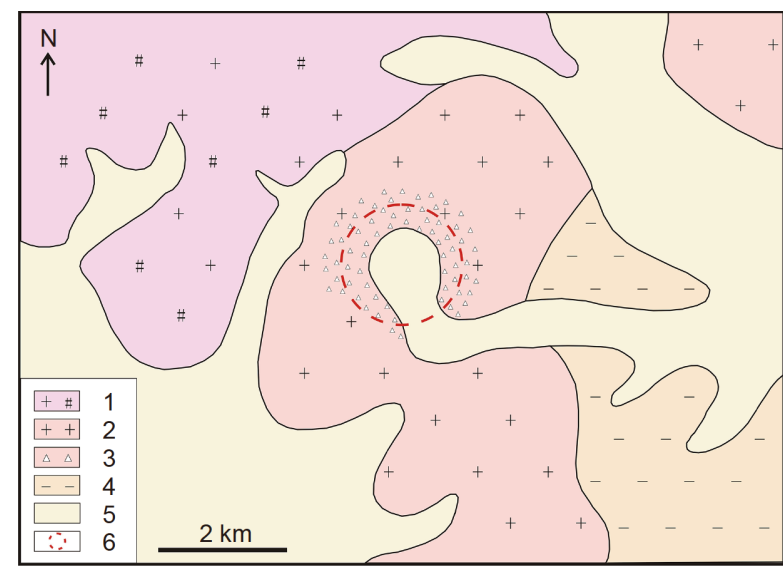

图 1 依兰陨石坑区域地质示意图. 根据依兰幅(1:200000)地质图绘 制 $^{[14]} .1$, 二叠纪碱性花岗岩; 2 , 白严纪碱性花岗岩; 3 , 花岗岩角砾堆 积; 4 , 第四纪土壤; 5 , 第四纪冲积层; 6 , 陨石坑位置

Figure 1 Schematic geological map of Yilan crater after Yilan Geological Map $(1: 200000)^{[14]}$. 1, Permian alkali-feldspar granite; 2, cretaceous alkali-feldspar granite; 3 , granite breccia; 4, quaternary soil; 5 , quaternary alluvial deposits; 6 , position of Yilan crater

地表，以凸起的环形山脊产出. 全景图像显示，陨石坑 是由一条连续但没有封闭的环形山脊围绕一个圆形洼 地构成, 坑底相对平坦, 坑缘内壁陡峭(图2(a)). 鸟瞰陨 石坑为一个正圆形(图2(b))，地形模型等高线同样呈现 为一个圆形轮廓(图2(c)). 坑底中心点的海拔高度为 $170 \mathrm{~m}$ ，坑缘山脊顶端与坑底之间的最大高差为 $150 \mathrm{~m}$. 坑缘山脊顶端高出周围地表70 120 m.

坑体南部占总长度约三分之一的坑缘(弧长约 $2 \mathrm{~km}$ ) 被侵蚀到与坑底大致相同的高度. 在受到强烈侵 蚀的南南东坑缘位置测得的海拔高度为 $160 \mathrm{~m}$, 比坑底 中心高度低约 $10 \mathrm{~m}$. 由于南部坑缘的大规模缺失, 陨石 坑内部洼地与坑外东南部一条长达数公里, 而且下降 坡度的宽阔槽状凹地以及巴兰河谷连接在一起(图 2(c)).

坑缘主要由松散堆积的花岗岩碎屑和花岗岩砾石 构成. 坑底被土壤、湖相沉积物和花岗岩碎屑和角砾 等充填. 坑底表面覆盖着一层厚度为 $30 \sim 90 \mathrm{~cm}$ 的黑褐 色土壤. 在坑底离坑壁大约 $200 \mathrm{~m}$ 的区域，花岗岩碎屑 和角砾堆积被土壤层覆盖. 图3(a)是通过人工岩土工程 在坑底揭露出在土壤层覆盖下的松散花岗岩角砾和碎 屑堆积. 在坑底中央直径约 $1 \mathrm{~km}$ 区域, 表面土壤层之下 覆盖的是湖泊相沉积物. 这些湖泊相沉积物主要由黏 土-淤泥、砂质黏土、细沙砾等组成. 根据土壤、湖相 沉积物和花岗岩角砾堆积之间的产状关系, 湖相沉积 物的下伏物质应为花岗岩碎屑和角砾堆积. 
(a)

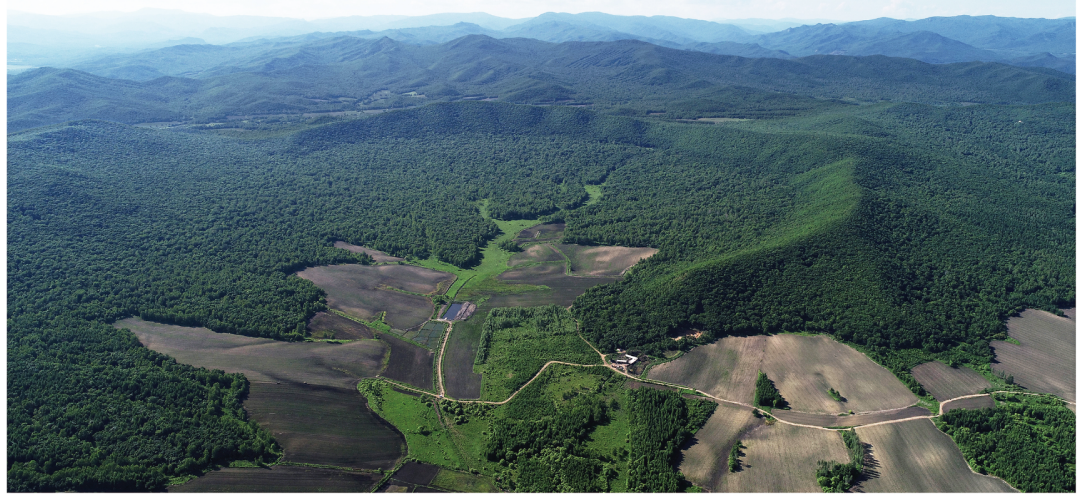

(b)
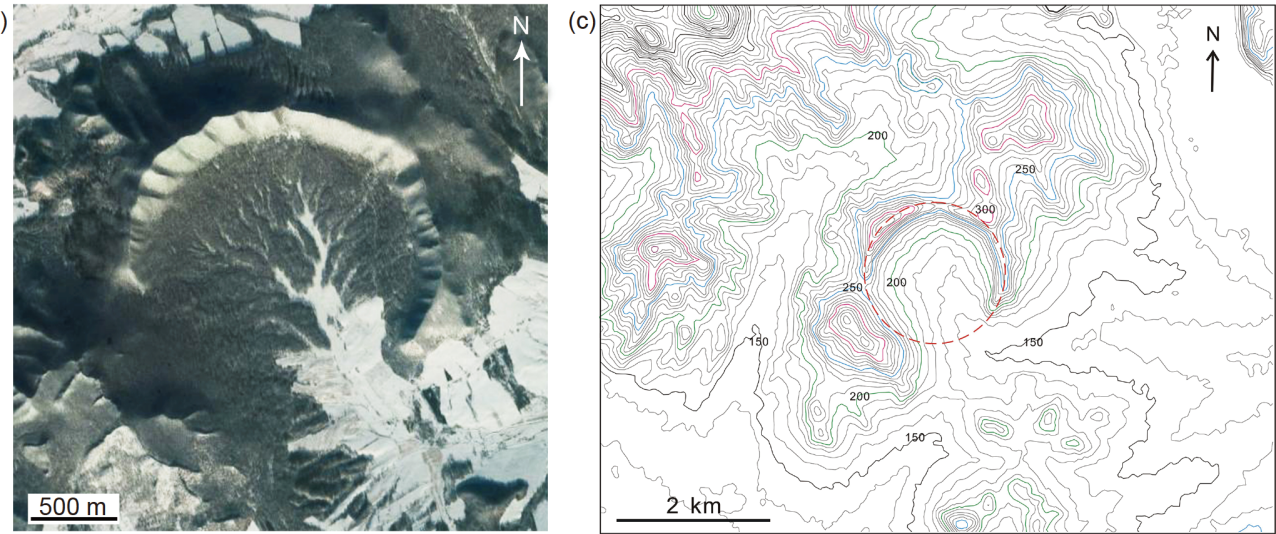

图 2 依兰陨石坑图像. (a) 陨石坑全景照片, 无人机拍摄. 陨石坑大部分区域被密集森林覆盖; (b) 陨石坑卫星遥感图像(Google Earth 2013 年12 月7日资料); (c) 等高线地形图, 圆形虚线表示陨石坑位置

Figure 2 Images of Yilan crater. (a) A panoramic photograph of the crater. Most regions of the crater are covered with dense forests; (b) a satellite image of the crater (taken on 7 December 2013) from Google Earth; (c) a hypsographic map. The red dashed circle on the map indicates the position of Yilan crater
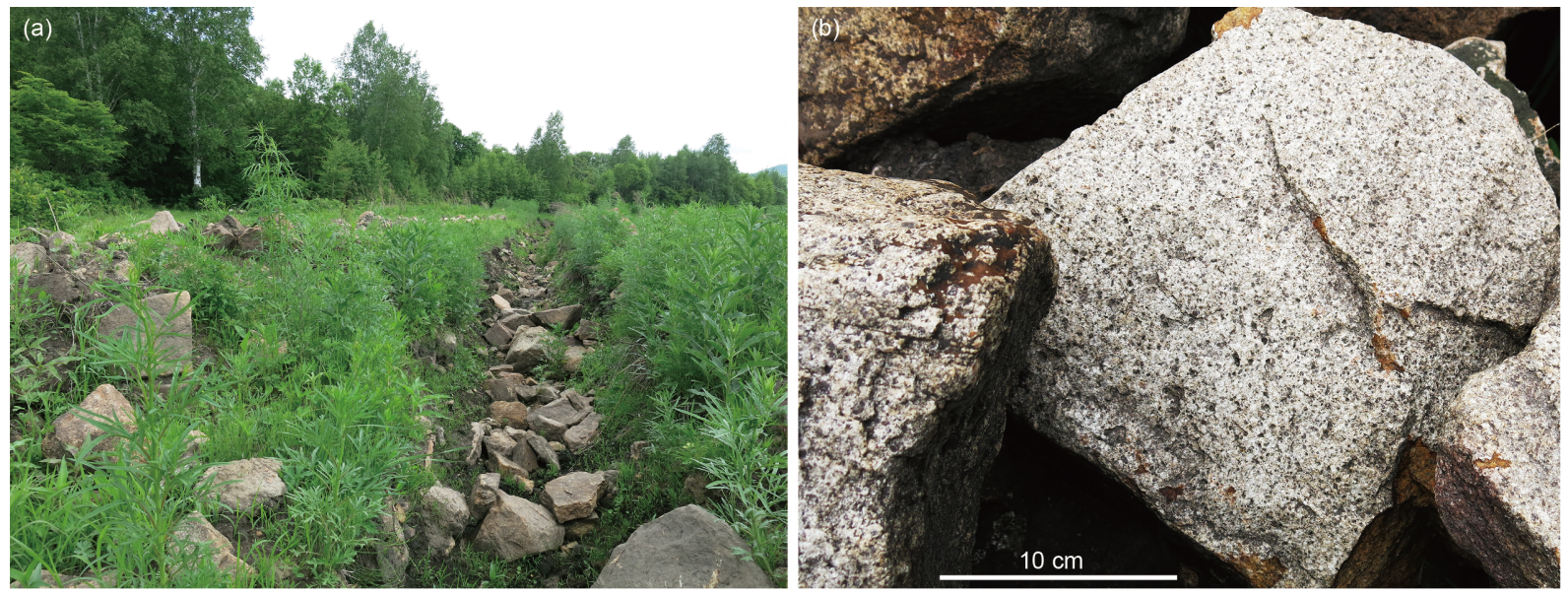

图 3 陨石坑底部充填的花岗岩角砾堆积. (a) 陨石坑底部人工沟槽揭露土壤薄层之下的花岗岩角砾堆积, 沟槽深度 $60 \mathrm{~cm}$, 沟槽距离坑体内壁 约为 $100 \mathrm{~m}$. (b) 新鲜的花岗岩角砾

Figure 3 Crater-filled breecia. (a) An artificial groove $60 \mathrm{~cm}$ in depth on the surface of crater floor discloses a number of fragments of granite which were covered by a thin layer of soil, where is $100 \mathrm{~m}$ to the crater wall; (b) fresh fragments of granite 
为了了解湖泊消失的时间，我们在坑底中心土壤 和湖相沉积物界面附近采集了样品. 坑底中心土壤与 湖相沉积物界面深度为 $90 \mathrm{~cm}$. 采集的土壤和湖相沉积 物样品碳含量为 $0.16 \% \sim 2.45 \% .{ }^{14} \mathrm{C}$ 年龄测定结果为: 深

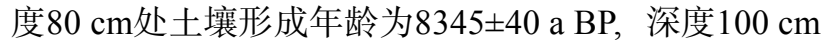
处湖泊相沉积物形成年龄为 $11140 \pm 47$ a BP.

\section{3 石英冲寺变质特征}

依兰陨石坑的基底岩石为碱性长石花岗岩．花岗 岩的石英含量约占 $35 \%$. 靶区岩石丰富的石英含量为 调查撞击产生的冲击波效应提供了理想的样品. 我们 将陨石坑冲击变质特征研究重点放在了对石英面状变 形页理的调查. 石英面状变形页理是近几十年来国际 科学界在地球陨石坑判别中使用最广泛的冲击变质诊 断性证据之一 ${ }^{[6 \sim 10]}$.

在陨石坑底部通过人工挖掘收集的岩石样品被划 分为两组：一组为 $5 \sim 30 \mathrm{~cm}$ 大小的花岗岩角砾, 岩石普 遍比较新鲜(图3(b)); 另一组为粒度小于 $3 \mathrm{~mm}$ 的岩石和 矿物碎屑. 在第一组 55 个花岗岩角砾样品制作的薄片 中，没有观察到含有PDFs的石英颗粒. 在第二组岩石 和矿物碎屑样品中, 发现了许多含有PDFs的石英颗粒. 在130个碎屑样品制作的薄片中，54个薄片发现了含有 PDFs的石英颗粒. 图4(a)显示了花岗岩碎屑中石英颗粒 发育的PDFs. 图5显示薄片中石英颗粒在正交偏光显微 镜下的PDFs图像. 另外, 在从碎屑样品中挑选出的石英 颗粒中也直接观察到了PDFs的存在. 图4(b), (c)分别显 示挑选出来的石英碎屑的2组和3组密集PDFs.

石英PDFs通常以一组到多组平行于石英晶体特定 晶面方位的页理产出. 在依兰陨石坑的岩石和矿物碎屑 样品中，观察到含有1 4组PDFs的石英颗粒. 测得的 PDFs晶面指数(Miller指数)包括(0001)，\{1010 $\} ，\{1011\}$, $\{1013\}$ 和 $\{1012\}$ 等. 在含PDFs石英颗粒中，大部分颗粒 发育 1 组PDFs，大约 $20 \%$ 的颗粒含PDFs 发育 $2 \sim 4$ 组的 PDFs. 发现的石英PDFs特征比较典型, 页理薄层明锐和 平直, 单层页理厚度为 $1 \sim 2 \mu \mathrm{m}$, 同组页理之间的间距为 $1 \sim 8 \mu \mathrm{m}$, 页理延伸至整个石英颗粒或部分切割石英颗粒.

\section{3 讨论}

\section{1 一个简单碗形陨石坑}

依兰陨石坑直径为 $1.85 \mathrm{~km} ，$ 坐落在巨大的花岗岩 基岩上．根据地球陨石坑直径、基岩性质和陨石坑类
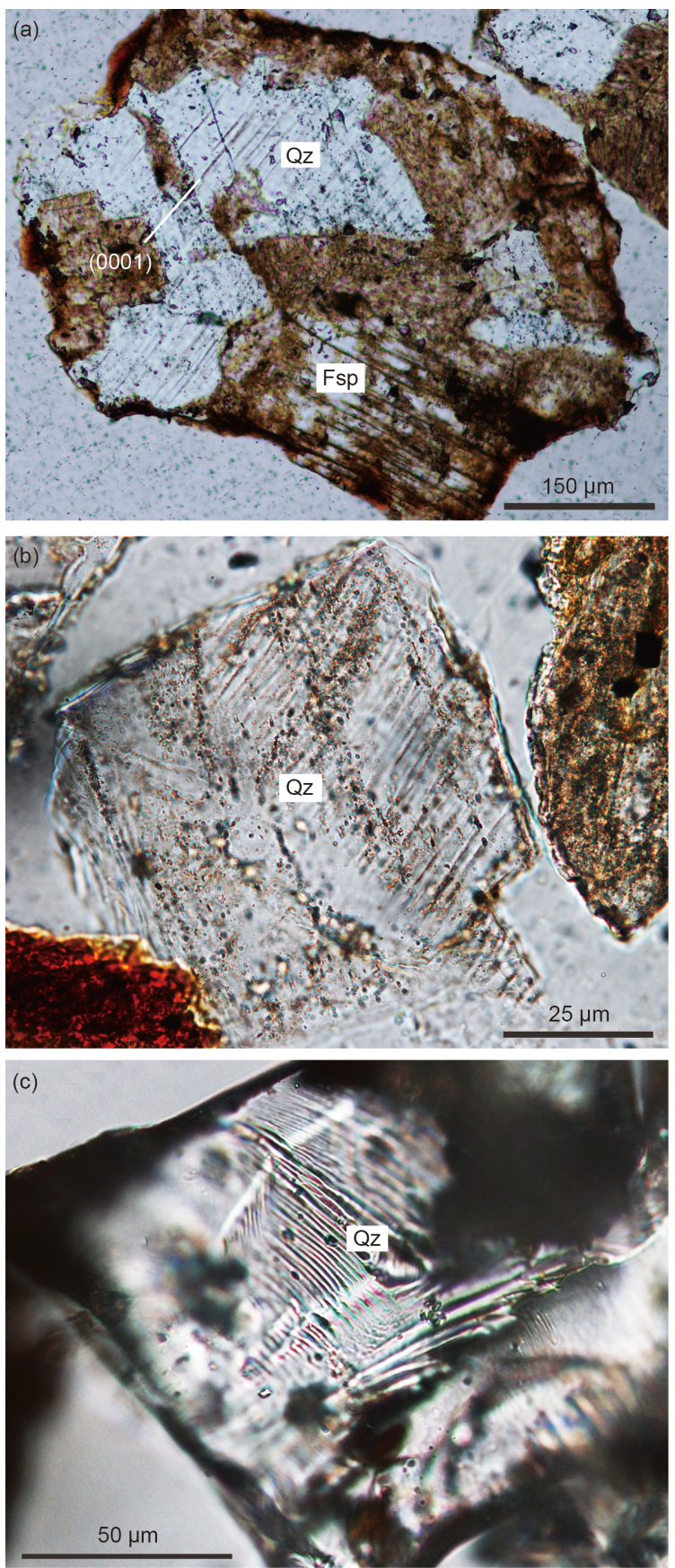

图 4 岩石和矿物碎屑中的含PDFs的石英颗粒. (a) 花岗岩碎屑中石 英发育一组平行于 $(0001)$ 的PDFs(NE-SW方向), 单偏光; (b) 石英晶体 碎片含2组PDFs(分别为北东-南西和北北西-南南东方向), 单偏光; (c) 石英晶体碎片含3组PDFs(分别为北西-南东、北-南和北东东-南西西 方向)的石英, 单偏光; Qz: 石英, Fsp: 长石

Figure 4 PDFs-bearing granite and quartz clasts. (a) A granite clast containing quartz grains with one set of PDFs parallel to (0001) (running NE-SW) under plane-polarized light; (b) a quartz clast containing two sets of PDFs (running NE-SW and NNW-SSE) under plane-polarized light; (c) a quartz clast containing three sets of PDFs (running NW-SE, $\mathrm{N}-\mathrm{S}$ and NEE-SWW) under plane-polarized light; Qz, quartz; Fsp, feldspar 

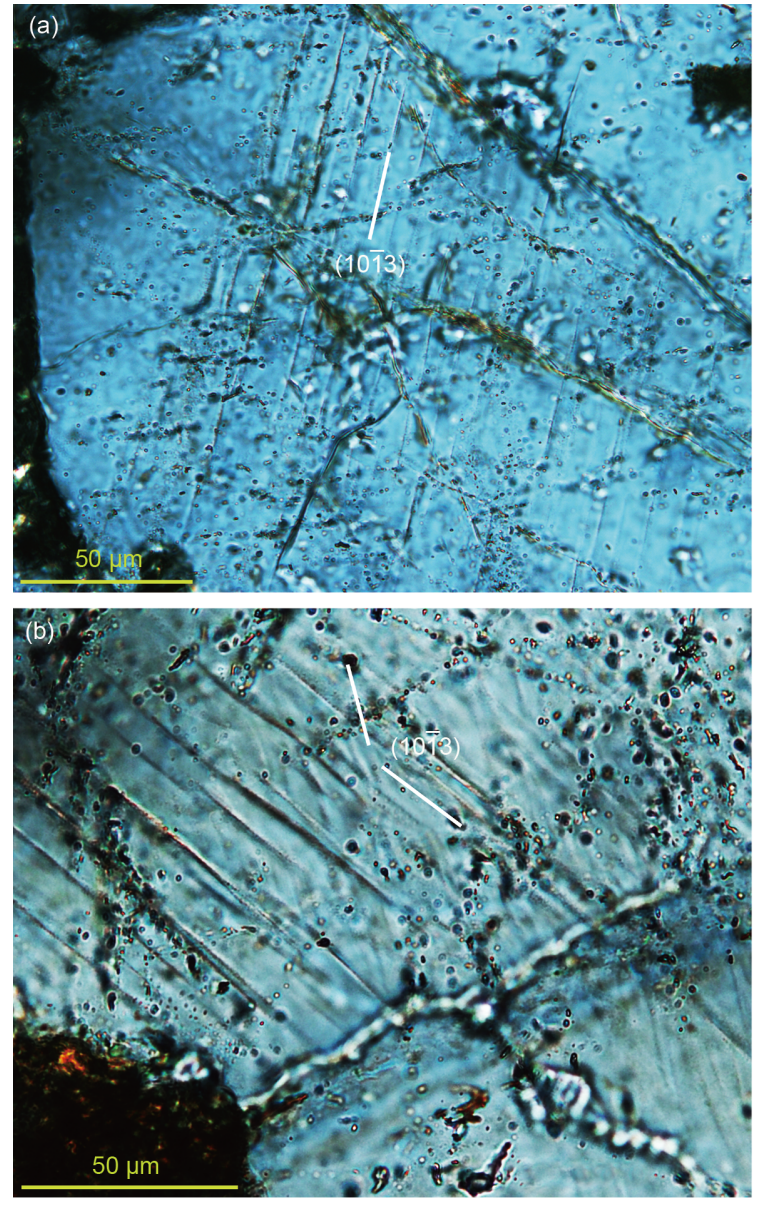

图 5 正交偏光下的石英PDFs图像. (a) 一组平行于 $\{10 \overline{1} 3\}$ 的PDFs; (b) 二组平行于 $\{10 \overline{1} 3\}$ 的PDFs

Figure 5 PDFs in quartz observed under cross-polarized optical microscope. (a) One set of PDFs parallel to $\{10 \overline{1} 3\}$; (b) two sets of PDFs parallel to $\{10 \overline{1} 3\}$

型之间的关系 ${ }^{[9]}$ ，依兰陨石坑是一个简单碗形陨石坑. 大部分坑缘保存状态良好，三分之一的坑缘被强烈侵 蚀. 除了地表广泛发育的薄层土壤之外, 陨石坑底部的 主要填充物质为撞击产生的花岗岩角砾和碎屑以及湖 泊相沉积物. 湖相沉积物的存在表明该陨石坑的坑缘 最初是连续和封闭, 坑内曾发育为一个湖泊. 根据坑底 土壤和湖泊相沉积物的 ${ }^{14} \mathrm{C}$ 年龄分析, 湖泊消失或湖相 沉积终止在11.14 8.34 ka BP之间. 依兰陨石坑形成在 白严纪花岗岩基岩上，据此可以确定撞击成坑事件应 发生在 $<65 \mathrm{Ma}$ 前, 精确的成坑年龄有待进一步研究.

\section{2 撞击起源的证据}

简单陨石坑底部充填的撞击角砾岩单元主要来源 于靶岩受撞击后溅射回落的岩石碎块以及瞬态坑重力 调整阶段从坑缘和坑壁坍塌下来的岩石碎块, 是未冲
击变质、弱冲击变质、中等程度冲击变质和强烈冲击 变质的岩石和矿物碎块和碎屑的混合堆积 ${ }^{[9]}$. 陨石坑底 部充填的撞击角砾岩是寻找和发现冲击变质证据的重 要对象. 石英中PDFs形成要求冲击压力达到10 35 $\mathrm{GPa}^{[7 \sim 9]}$. 依兰陨石坑内底部堆积的花岗岩质撞击角砾 岩中石英PDFs的发现(图4,5), 提供了矿物冲击变质的 确丵证据. 因此, 该陨石坑含PDFs石英的发现证实了它 的星球撞击起源.

在收集的花岗岩碎屑样品中, 石英颗粒展示了不 同的冲击变质程度. 大部分石英颗粒没有发生明显的 冲击变质, 一部分发育了1 4组不等的PDFs. 石英多组 PDFs的发育主要与较高的冲击压力有关 ${ }^{[11,15]}$. 这表明 目前采样到的样品冲击变质程度相对较弱. 相关研究 表明 ${ }^{[16,17]}$, 与依兰陨石坑规模大小相似的陨石坑中的 强烈冲击变质物质, 通常大量产出在坑底撞击角砾岩 单元的底部位置，如岩石冲击熔融物质、石英和长石 击变玻璃以及矿物高压多形等. 我们的后续工作拟通 过地质钻探工程揭示和收集该陨石坑撞击角砾岩单元 中的强烈冲击变质物质.

\section{3 坑缘的侵蚀}

依兰陨石坑显示出奇特的侵蚀地形地貌特征. 陨 石坑大部分坑缘保存状态良好，但坑体南部缺失了一 段长度达 $2 \mathrm{~km}$ 的坑缘, 占坑缘总长度约三分之一. 坑缘 发生如此大规模缺失并非由构造运动或山体坍塌等原 因造成, 也不可能经由正常的风化侵蚀作用产生. 很显 然, 南部坑缘的大规模缺失与特定外部地质营力的方 向性侵蚀作用和搬运作用有关. 陨石坑环形洼地与坑 外东南部一条长达数千米而且下降坡度的宽阔槽状凹 地以及巴兰河谷相连通，表明受到侵蚀的坑缘岩石可 以沿着这一通道进行搬运(图2(c)). 在陆地上，流水作 用和冰川作用等外部地质营力可以导致地表岩石发生 大规模和方向性的侵蚀和搬运. 相对于岩性完整的花 岗岩基岩, 由松散岩石碎块堆积形成的坑缘更容易受 到流水和冰川的侵蚀和搬运.

然而，区域内没有河流流经该陨石坑. 陨石坑湖泊 的蓄水容量有限, 经由湖泊溃决洪水移走长达 $2 \mathrm{~km}$ 坑缘 巨大体积岩石的可能性不大. 我们注意到, 地球最后一 个冰河时期终止于距今大约 1 万年前 ${ }^{[18]}$. 近几十年来在 依兰陨石坑周边地区大量距今 4 万 1 万年的长毛猛犸 象和披毛犀化石的发现 ${ }^{[19,20]}$, 客观地表明了该区晚第四 纪冰期的极端寒冷气候. 依兰陨石坑湖泊的消失事件发 
生在大约 1 万年前. 据此分析, 南部坑缘的大规模侵蚀和 移去很可能与冰川作用有关. 后续研究将进一步揭示南 部坑缘大规模侵蚀的地质营力、作用机制和历史.

\section{4 结论}

依兰陨石坑是一个星球撞击遗迹，它的发现为我
国该类型地质构造增添了一个重要的新成员。撞击成 坑事件发生在 $<65 \mathrm{Ma}$ 前. 花岗岩质撞击角砾岩中石英 面状变形页理(PDFs)的发现为该坑的撞击起源提供了 确丵证据. 距今大约 1 万年前，南部坑缘在特定外力地 质作用下发生方向性的强烈侵蚀和搬运，造成坑缘大 规模缺失.

致谢＼cjkstart黑龙江省依兰县人民政府协助该项研究。依兰县文体广电和旅游局徐立星、王本昆、孙大成和李美洪以及依兰县迎兰 乡郭洪涛和李凤民协助了部分野外地质调查工作。中国科学院广州地球化学研究所曹裕波对研究提出了建设性意见. 中国科学院广州地球化学研究所丁平完成 ${ }^{14} \mathrm{C}$ 年代测定.

\section{参考文献}

1 The University of New Brunswick, Canada. Earth Impact Database. http://www.passc.net/EarthImpactDatabase/New\%20website_05-2018/Index. html, 2018

2 Chen M. Impact-derived features of the Xiuyan meteorite crater. Chin Sci Bull, 2008, 53: 392-395

$3 \mathrm{Xu}$ X, Kenkmann T, Xiao Z, et al. Reconnaissance survey of the Duolun ring structure in Inner Mongolia: Not an impact structure. Meteorit Planet Sci, 2017, 52: 1822-1842

4 Chen M, Xiao W S, Xie X D, et al. Xiuyan crater, China: Impact origin confirmed. Chin Sci Bull, 2010, 55: 1777-1781

5 McCall G J H. Impact crater breaks China duck. Geoscientist, 2012, 22: 8-9

6 Chao E C T. Shock effects in certain rock-forming minerals. Science, 1967, 156: 192-202

7 Stöffler D, Langenhorst F. Shock metamorphism of quartz in nature and experiment: I. Basic observation and theory. Meteoritics, 1994, 29: 155181

8 Grieve R A F, Langenhorst F, Stöffler D. Shock metamorphism of quartz in nature and experiment: II. Significance in geoscience. Meteorit Planet Sci, 1996, 31: 6-35

9 French B M. Traces of Catastrophe: A Handbook of Shock-metamorphic Effects in Terrestrial Meteorites Impact Structure. LPI Contribution 954. Houston, Texas: Lunar and Planetary Institute, 1998

10 Koeberl C. Mineralogical and geochemical aspects of impact craters. Mineral Mag, 2002, 66: 745-768

11 Ferrière L, Morrow J R, Amgaa T, et al. Systematic study of universal-stage measurements of planar deformation features in shocked quartz: Implications for statistical significance and representation of results. Meteorit Planet Sci, 2009, 44: 925-940

$12 \mathrm{Xu}$ X, Trumbore S E, Zheng S, et al. Modifying a sealed tube zinc reduction method for preparation of AMS graphite targets: Reducing background and attaining high precision. Nucl Instrum Methods Phys Res Sect B-Beam Interact Mater Atoms, 2007, 259: 320-329

13 Windley B F, Alexeiev D, Xiao W, et al. Tectonic models for accretion of the Central Asian Orogenic Belt. J Geol Soc, 2007, 164: 31-47

14 Heilongjiang Geological Bureau. Yilan Geological Map (L-52-XVI, 1:200000) (in Chinese). Regional Geological Investigation Reports, 1972 [黑 龙江省地质局. 依兰幅地质图(L-52-XVI, 1:200000). 区域地质调查报告, 1972]

15 Trepmann C A, Spray J G. Shock-induced crystal-plastic deformation and post-shock annealing of quartz: Microstructural evidence from crystalline target rocks of the Charlevoix impact structure, Canada. Eur J Mineral, 2006, 18: 161-173

16 Fredriksson K, Dube A, Milton D J, et al. Lonar Lake, India: An impact crater in basalt. Science, 1973, 180: 862-864

17 Chen M, Koeberl C, Xiao W, et al. Planar deformation features in quartz from impact-produced polymict breccia of the Xiuyan crater, China. Meteorit Planet Sci, 2011, 46: 729-736

18 Wurster C M, Bird M I, Bull I D, et al. Forest contraction in north equatorial Southeast Asia during the Last Glacial Period. Proc Natl Acad Sci USA, 2010, 107: 15508-15511

19 Jin C Z, Xu Q Q, Zheng J J. On the dispersal events of Mammuthus during the Late Late Pleistocene (in Chinese). Vert PalAs, 1998, 36 : 47-53 [ 金 昌柱, 徐钦琦, 郑家坚. 中国晚更新世猛犸象(Mammuthus)扩散事件的探讨. 古脊椎动物学报, 1998, 36: 47-53]

20 Hao Z G, Fei H C, Hao Q Q, et al. China has built a Mammoth museum. Acta Geol Sin, 2016, 90: 1039-1040 


\title{
Yilan crater, a newly identified impact structure in northeast China
}

\author{
Ming Chen ${ }^{1,2^{*}}$, Xiande $\mathrm{Xie}^{2}$, Wansheng Xiao ${ }^{2} \&$ Dayong $\operatorname{Tan}^{2}$ \\ ${ }^{1}$ State Key Laboratory of Isotope Geochemistry, Guangzhou Institute of Geochemistry, Chinese Academy of Sciences, Guangzhou 510640, China; \\ ${ }^{2}$ Key Laboratory of Mineralogy and Metallogeny, Chinese Academy of Sciences, Guangzhou 510640, China \\ * Corresponding author, E-mail: mchen@gig.ac.cn
}

This study reports the discovery of Yilan crater, a newly identified impact structure in northeast China. The crater has a rimto-rim diameter of $1.85 \mathrm{~km}$, and is located in Yilan County of Heilongjiang Province. The latitude and longitude coordinates of the crater are $46^{\circ} 23^{\prime} 03^{\prime \prime} \mathrm{N}$ and $129^{\circ} 18^{\prime} 40^{\prime \prime} \mathrm{E}$, respectively. The crater lies in a low mountainous and hilly area of the southwest border of the Xiaoxinganling mountain range. Most of the crater is covered with dense forests. Geotectonically, the area belongs to the eastern Central Asian Orogenic Belt where strong tectonic and magmatic activities have occurred since the late Proterozoic. The crater was entirely formed within the bedrock of Cretaceous granite and appears as a bowl-shaped structure. Approximately one-third of the southern part of the crater rim has been significantly eroded and mostly removed; otherwise, most of the crater rim is well preserved. In a panoramic view, the crater appears as an unclosed ring mountain surrounding a circular depression, and it has steep walls and a relatively flat floor. The crater rim raises approximately $70-120 \mathrm{~m}$ above the surrounding terrain. The maximum elevation of the crater rim over the present crater floor is approximately $150 \mathrm{~m}$. Most of the crater rim is composed of granite impact breccia varying from granules to boulders in size. The crater's interior has been filled by a large amount of granite impact breccia at the bottom and lacustrine deposits at the top. The target rock of granite contains abundant quartz. This study investigated the planar deformation features (PDFs) in the quartz, which is one of the commonest shock metamorphic features in numerous terrestrial impact structures. For the investigation, granite impact breccia was collected from the crater floor. Most of the samples were made into polished thin sections for identifying the PDFs in quartz. Some fine-grained fragments of quartz were also collected from the samples for observation and analysis. The crystallographic orientations of the quartz PDFs were observed on a 4-axis universal stage under an optical microscope. No PDFs in quartz were observed in the quartz of large granite breccia fragments, but many PDFs appeared in the quartz of the fine-grained samples. One to four sets of PDFs in quartz were observed. The forms of the PDFs with Miller indices, such as (0001), $\{10 \overline{1} 1\}$ and $\{10 \overline{1} 3\}$, were indexed. The observed multiple sets of PDFs in quartz provide unambiguous evidence of shock-metamorphism and confirm an impact origin of the structure. The topographic and structural features of the crater, as well as the occurrences of crater-filled materials (impact breccia and lacustrine deposits), characterize a bolide impact site. Based on ${ }^{14} \mathrm{C}$ dating of the lacustrine deposits from the crater floor, the Crater Lake disappeared approximately $10 \mathrm{ka}$ ago; this disappearance can be related to the loss of crater rim in the southern part of the crater. The large-scale absence of the crater rim cannot be explained by tectonic activity, normal weathering, or erosional process, and must correspond to directional erosion caused by a specific exogenic geological process after the formation of the impact crater. The geologic agent, mechanism, and history of the strong erosion of the crater rim require further investigation. The Yilan crater is the second confirmed impact structure in a large country (China) with an area of 9.6 million square kilometers.

Yilan crater, impact structure, shock metamorphism, planar deformation features, erosion doi: 10.1360/TB-2019-0704 